DOI: $10.19195 / 2084-5065.50 .9$

\title{
Wymiar sprawiedliwości przyjazny dziecku - perspektywa prawno-psychologiczna
}

\author{
SYlWia SKUBISZ-ŚLUSARCZYK \\ ORCID: 0000-0003-1172-8286 \\ Katedra Kryminalistyki \\ Wydział Prawa, Administracji i Ekonomii, Uniwersytetu Wrocławskiego
}

„Wymiar sprawiedliwości przyjazny dziecku” to hasło, slogan, truizm powielany w kolejnych publikacjach i materiałach — czy może jednak w tym stwierdzeniu jest pewien przekaz wymagający zastanowienia, przeanalizowania i sformułowania kilku wniosków na przyszłość. Jak wskazuje ostatnie sprawozdanie ${ }^{1}$ Agencji Praw Podstawowych Unii Europejskiej, dzieci biorące udział w postępowaniach sądowych często są wystraszone, ignorowane i niedoinformowane, a nowa sytuacja, w jakiej się znalazły, powoduje u nich poczucie niepewności i zagrożenia. Dlatego też należy się

1 Wiedeń, 22 lutego 2017 roku, sprawozdanie „Child-friendly justice: Perspectives and experiences of children involved in judicial proceedings" (,Wymiar sprawiedliwości przyjazny dziecku: opinie i doświadczenia dzieci uczestniczących w postępowaniach sądowych") sporządzono na podstawie rozmów z 392 dziećmi. Określono w nim bariery, z jakimi zmagają się dzieci, oraz możliwe rozwiązania i wiele obiecujących praktyk stosowanych obecnie w państwach członkowskich UE, http://fra.europa.eu/en/publication/2017/child-friendly-justice-childrens-view (dostęp: 6.10.2017). Ustalenia te opierają się na rozmowach przeprowadzonych z dziećmi w państwach członkowskich: Bułgarii, Chorwacji, Estonii, Francji, Hiszpanii, Niemczech, Polsce, Rumunii. Sprawozdanie to uzupełnia wcześniejsze sprawozdanie Agencji Praw Podstawowych zawierające opinie specjalistów na temat wymiaru sprawiedliwości przyjaznego dziecku, http://fra.europa.eu/ en/press-release/2015/justice-needs-be-more-child-friendly-finds-fra (dostęp: 6.10.2017). 
zastanowić, czy gwarancje proceduralne są wystarczające i zaspokajają potrzeby dzieci w obszarze nie tylko prawnym, lecz także psychologicznym.

Niniejszy artykuł ma na celu przeanalizowanie możliwości prawnych, jakie oferuje wymiar sprawiedliwości w zakresie przychylnego dziecku prowadzenia postępowania. Rozważania odnoszą się w przeważającym obszarze do instytucji wysłuchania realizowanej na gruncie procedury cywilnej, choć odwołanie do procedury karnej, kryminalistyki i psychologii jest wyraźnym elementem eksponowanym w trakcie przemyśleń. Taki stan rzeczy wynika z przedmiotu zainteresowania wskazanych nauk, którym jest ludzkie zachowanie, zrozumienie go i podjęcie odpowiedniego działania.

Prawo i psychologia ${ }^{2}$ stanowią nierozłączny duet, zwłaszcza w sytuacji, kiedy rozpatrywany problem znajduje się na pograniczu obu dziedzin bądź do jego „zdiagnozowania” i zbadania niezbędne jest ich współdziałanie. Różnorodność problematyki psychologicznej powoduje, że na każdym etapie postępowania zarówno karnego, jak i cywilnego jest możliwość, a niekiedy wręcz konieczność zastosowania praktyki psychologicznej. To powoduje, że wymiar sprawiedliwości w coraz szerszym zakresie korzysta ze współczesnej wiedzy psychologicznej.

Przegląd definicji proponowanych w literaturze specjalistycznej ${ }^{3}$ w celu jednoznacznego dookreślenia przedmiotu i zakresu badań i praktyki psychologicznej stosowanej na użytek prawa nie jest jednoznaczny. Główną przyczyną takiego stanu rzeczy jest różnorodność problematyki

2 W latach 90. XX wieku wprowadzono formułę ,psychologia i prawo”, podkreślając wzajemne związki prawa i psychologii w zakresie teorii oraz praktyki. Zob. m.in. J.K. Gierowski, T. Jaśkiewicz-Obydzińska, M. Najda, Psychologia w postepowaniu karnym, Warszawa 2008, s. 10 n.

3 Współczesna psychologia to nauka, która zajmuje się procesami psychicznymi i zachowaniem człowieka. W zakres jej zainteresowań wchodzą badania nad świadomością człowieka, jego stanami emocjonalnymi, procesami związanymi z poznaniem, rolą zamysłów, doświadczeniem wewnętrznym, wyobrażeniami oraz regulatorami stosunków człowieka $\mathrm{z}$ otoczeniem i zasadami ich funkcjonowania. zob. A. Trzecieniecka-Green, Psychologia, Kraków 2006, s. 16. 
psychologicznej mieszczącej się w tym obszarze. W dzisiejszych czasach psychologia w znaczeniu „nauka o duszy” jest pewnego rodzaju anachronizmem, ponieważ współczesna psychologia składa się z bardzo wielu działów wykorzystujących odpowiednie metody badawcze. Każdy proces będący przedmiotem badań psychologicznych można z kolei analizować z różnych punktów widzenia, co spowodowało wyodrębnienie osobnych dziedzin podporządkowanych psychologii ${ }^{4}$. W nauce psychologii można wyróżnić dwa podstawowe działy: psychologia teoretyczna i stosowana. Ze względu na rodzaj podejmowanych badań można zaproponować podział psychologii na ogólną, rozwojową i społeczną. Natomiast praktyczny wymiar psychologii daje możliwość podziału na psychologię wychowawczą, pracy i kliniczną. W ramach psychologii klinicznej, będącej działem psychologii stosowanej, można wyróżnić psychologię sądową ${ }^{5}$.

Termin forensic psychology został po raz pierwszy użyty w 1953 roku, wówczas zdefiniowano psychologię sądową jako dziedzinę zajmującą się zbieraniem, badaniem i przedstawianiem dowodów dla celów sądowych ${ }^{6}$. To ujęcie niewątpliwie ogranicza przedmiot zainteresowania psychologii sądowej do problematyki związanej z opracowywaniem ekspertyz sądowych, co nie jest satysfakcjonujące zarówno dla prawników, jak i psychologów. Praktyka wskazuje, że zakres zagadnień wymagających wyjaśnienia i poznania niekiedy leży na pograniczu prawa i psychologii, a do ich wythumaczenia wymagane są wiadomości także z innych obszarów stosowania wiedzy psychologicznej, nie tylko tej sądowej. $Z$ tego powodu w literaturze zaproponowano podział uwzględniający wszystkie działania podejmowane przez psychologów na rzecz wymiaru sprawiedliwości. W ramach takiego wy-

${ }^{4}$ P. Fraisse, Podręcznik ćwiczeń z psychologii eksperymentalnej, Warszawa 1960, s. $15-17$.

5 E. Gruza, Psychologia sądowa dla prawników, Warszawa 2009, s. 19 n.

${ }^{6}$ J.K. Gierowski, T. Jaśkiewicz-Obydzińska, M. Najda, op. cit., s. 155, cyt. za: G. Gudjonsson, L. Howard, Forensic Psychology. A guide to practice, London-New York 1988. Podobne stanowisko reprezentują inni: „psychologia sądowa polega na dostarczaniu informacji psychologicznych w celu ułatwienia podejmowania decyzji prawnych" - D. Howitt, Introduction to Forensic and Criminal Psychology, London-New York 2006, s. 22 n. 
odrębnienia dokonano podziału na psychologię sądową i kryminalną ${ }^{7}$. Nie jest to podział jedyny, gdyż różnorodność zagadnień, dla wyjaśnienia których prawo sięga obecnie do ustaleń psychologii, spowodowała wyselekcjonowanie jeszcze bardziej specjalistycznych działów. Ze względu na etap postępowania, w którym występuje psycholog, wy-

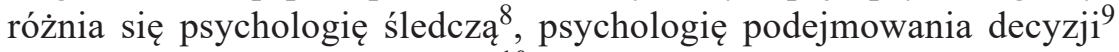
oraz psychologię penitencjarną ${ }^{10}$. Natomiast podstawą wyodrębnienia psychologii zeznań i wyjaśnień, psychologii kryminalnej czy też psychologii rodziny są konkretne problemy, które rozważa, analizuje i na które poszukuje rozwiązania psycholog. Zaprezentowany podział nie jest do końca jednoznaczny, gdyż bywają okoliczności, kiedy problematyka wyodrębnionych działów się pokrywa. Taki stan rzeczy wynika między innymi z sytuacji stale postępującego rozwoju psychologii sądowej, a to natomiast generuje częstszy udział psychologów w działaniach wymiaru sprawiedliwości ${ }^{11}$.

Przedmiotem rozważań są możliwości, jakie oferuje wymiar sprawiedliwości w zakresie przyjaznego dziecku prowadzenia postępowania, lecz także zachowanie ochrony — zwłaszcza psychologicznej — przed

7 Zdaniem niektórych termin „sądowa” odnosi się do wąskiej dziedziny badań i praktyki psychologów pracujących bezpośrednio dla sądu. Natomiast przedmiotem psychologii kryminalnej są wszelkie psychologiczne aspekty zachowań przestępczych. W zakresie psychologii kryminalnej mieści się także obszar działań psychologów więziennych i psychologów pracujących w ośrodkach dla sprawców z zaburzeniami psychicznymi. J. K. Gierowski, T. Jaśkiewicz-Obydzińska, M. Najda, op. cit., s. 156, cyt. za: D. Howitt, op. cit. Pojawiają się w literaturze także głosy traktujące zakres psychologii sądowej szerzej, wskazując, że każde zastosowanie wiedzy psychologicznej lub metod używanych w psychologii w zadaniach realizowanych $\mathrm{w}$ obrębie systemu prawa ma związek z tą właśnie dziedziną psychologii. J.K. Gierowski, T. Jaśkiewicz-Obydzińska, M. Najda, op. cit., s. $156-157$.

${ }^{8}$ Zajmuje się psychologicznymi zasadami prowadzenia śledztwa, ustalania strategii postępowania i uzyskiwania dowodów osobowych.

9 Bada mechanizmy podejmowania decyzji w sądzie.

${ }^{10}$ Koncentruje się na analizie funkcjonowania osób w środowisku więziennym i problematyce ich resocjalizacji.

11 Psycholog bada również sposoby, jakimi prawo reaguje na przemiany społeczne wymagające zmian prawa. Pogląd taki reprezentują m.in. D. Carson i R. Bull; zob. J.K. Gierowski, T. Jaśkiewicz-Obydzińska, M. Najda, op. cit., s. 157, cyt. za: D. Carson, R. Bull, Psychology in legal contexts: Idealism and realism, [w:] Handbook of Psychology in Legal Contexts, red. D. Carson, R. Bull, Chichester 1995. 
negatywnym wpływem działań podejmowanych przed, w trakcie i po zakończeniu odpowiednich procedur. Elementy psychologicznej ochrony można zaobserwować między innymi w zakresie przeprowadzania czynności przesłuchania w ramach procedury karnej i cywilnej ${ }^{12}$ oraz wysłuchania w ramach procedury cywilnej ${ }^{13}$.

W psychologii sytuacje przesłuchania oraz wysłuchania ujmowane są jako proces komunikacji interpersonalnej. Jest to proces przekazywania i otrzymywania informacji w bezpośrednim kontakcie z drugą osobą. Droga komunikacji może być werbalna - świadoma - oraz niewerbalna, nie zawsze kontrolowana. Informacje przekazywane są za pomocą słów, mimiki, gestów, pozycji ciała, przyjmowania określonej postawy wobec rozmówcy, co może być różnie odbierane i interpretowane. Należy podkreślić, że sytuacja przesłuchania czy też wysłuchania ma swoją specyfikę, charakteryzuje ją nierówna pozycja nadawcy i odbiorcy. Osoba przesłuchująca, jak również wysłuchująca, reprezentuje sąd, ma wiedzę, jest świadoma spotkania, kieruje czynnością, zadaje pytania, zmierzając do uzyskania określonych informacji. Osoba przesłuchiwana czy też wysłuchiwana jest źródłem informacji, ma pewne obowiązki, podlega ocenie i nie ma pewności co do konsekwencji składanej relacji. O prawidłowościach tych warto pamiętać i brać je pod uwagę zwłaszcza w sytuacji, gdy wskazanym czynnościom poddawane jest dziecko ${ }^{14}$. Dobro dziecka musi mieć zapewnioną ochronę w trakcie realizacji zadań wymiaru sprawiedliwości.

Jednak w praktyce sądowej nie istnieje stan idealny, w którym dobro dziecka jest nienaruszone, bywają sytuacje, w których w mniejszym lub większym stopniu dobro jest zagrożone albo nawet zostaje naruszone.

12 O ile w procedurze karnej istnieją odpowiednie uregulowania prawne, o tyle w procedurze cywilnej nie są one tak wyraźnie artykułowane. Zob. m.in. art. 185a-d k.p.k., Ustawa kodeks postępowania karnego z dnia 6 czerwca 1997 roku, Dz.U. z 1997 r. Nr 89, poz. 555 z późn. zm. art. 259, 267 k.p.c., Ustawa kodeks postępowania cywilnego z dnia 23 kwietnia 1964 roku, Dz.U. z 1964 r. Nr 16, poz. 93 z późn. zm. Dowód z zeznań świadka przewiduje także kodeks postępowania administracyjnego w art. $83 \S 1$, Ustawa kodeks postępowania karnego z dnia 14 czerwca 1960 roku, Dz.U. z 1960 r. Nr 30, poz. $168 \mathrm{z}$ poźn. zm.

13 Art. $216^{1}$ k.p.c., art. $576 \S 2$ k.p.c., Ustawa kodeks postępowania cywilnego z dnia 23 kwietnia 1964 roku, Dz.U. z 1964 r. Nr 16, poz. 93 z późn. zm.

14 J.K. Gierowski, T. Jaśkiewicz-Obydzińska, M. Najda, op. cit., s. 266-267. 
Prawidłowo skonstruowane i stosowane przepisy stanowią gwarancję prawidłowości ochrony dobra dziecka. Samo znaczenie terminu „dobro dziecka" jest niewystarczające, dodatkowo należy ustalić, na czym polega ochrona tego dobra. Zasada ochrony dobra dziecka występuje nie tylko w postaci ogólnej dla całego prawa ${ }^{15}$, lecz także w odmianach szczegółowych, którym odpowiada określona grupa przepisów materialnych i procesowych, tworząc pewne kompleksy norm, które urzeczywistniają wskazane zasady. Ich realizacja dokonuje się w toku stosowania przepisów prawnych.

Każdego roku tysiące dzieci uczestniczy we wszystkich rodzajach postępowań, a konsekwencją takiego działania jest zapewnianie dzieciom lepszej ochrony w ramach systemów sądowych, tak aby zwiększyć stopień ich aktywnego udziału w postępowaniach i tym samym przyczynić się do zwiększenia efektywności wymiaru sprawiedliwości. Obowiązujące w Polsce procedury prawne dopuszczają udział małoletniego w prowadzonym postępowaniu nie tylko karnym, lecz także cywilnym, przy czym może on uczestniczyć w różnych rolach procesowych jako pokrzywdzony, świadek, sprawca czynu zabronionego, a także może być stroną toczącego się postępowania. Występując w każdej z tych ról, należy mu się stosowna ochrona, nie tylko prawna, lecz także — a może nawet przede wszystkim — psychologiczna.

15 Na przykład Wytyczne Komitetu Ministrów Rady Europy w sprawie wymiaru sprawiedliwości przyjaznego dzieciom, przyjęte przez Komitet Ministrów Rady Europy w dniu 17 listopada 2010 roku wraz z uzasadnieniem, http://fdds.pl/wp-content/uploads/2016/05/Wytyczne-Komitetu-Ministr\%C3\%B3w-Rady-Europy-dot.-wymiaru-sprawiedliwo $\%$ C5\%9Bciprzyjaznego-dla-dzieci.pdf (dostęp: 10.10.2017). Wymiar sprawiedliwości przyjazny dziecku — opinie i doświadczenia specjalistów, http://fra.europa.eu/sites/default/files/fra-2015-childfriendly-justice-professionals-summary_pl_0.pdf(dostęp: 10.10.2017). 


\section{II}

Instytucję wysłuchania małoletniego ${ }^{16}$ wprowadzono do kodeksu postępowania cywilnego nowelą z 6 listopada 2008 roku $^{17}$ jako jedna $\mathrm{z}$ konsekwencji zmian kodeksu rodzinnego i opiekuńczego. Przepis art. $216^{1}$ k.p.c. odnosi się do postępowań rozstrzyganych $\mathrm{w}$ procesie, a jego odpowiednikiem w postępowaniu nieprocesowym jest art. $576 \S$ 2 k.p.c. Pierwszy z wymienionych przepisów w $§ 1$ obliguje sąd do wysłuchania dziecka w każdej sprawie, która dotyczy jego osoby. Jednak obowiązek ten uzależniony jest od rozwoju umysłowego, stanu zdrowia i stopnia dojrzałości małoletniego. Natomiast $§ 2$ art. $216^{1}$ k.p.c. zobowiązuje sąd do uwzględnienia zdania i rozsądnych życzeń dziecka stosownie do okoliczności, rozwoju umysłowego, stanu zdrowia i stopnia dojrzałości. W postępowaniu nieprocesowym sąd ma obowiązek wysłuchania małoletniego także w sprawach dotyczących jego majątku, jednak z zastrzeżeniem, że pozwalają na to rozwój umysłowy dziecka, stan zdrowia i stopień dojrzałości. Brzmienie wymienionych przepisów wskazuje na obligatoryjny charakter przeprowadzenia czynności wysłuchania, choć w doktrynie zarysowały się różnice dotyczące obowiązkowości dokonania tej czynności oraz sposobu jej przeprowadzenia ${ }^{18}$. Jurydyczny tekst

16 Terminy „małoletni” i „dziecko” używane są zamiennie, co prawda nie są wprost wyjaśnione w przepisach kodeksu karnego czy cywilnego, jednakże wnioskowanie a contrario oraz interpretacja poszczególnych zapisów pozwala na takie ich traktowanie. Zgodnie z art. 10 § 1 k.c., pełnoletniość uzyskuje się z chwilą ukończenia 18 lat lub z chwilą zawarcia przez małoletniego związku małżeńskiego — art. $10 \S 2$ k.c. Ustawa z dnia 23 kwietnia 1964 roku Kodeks Cywilny, tekst jedn. Dz.U. z 2014 r. poz. 121 z późn. zm. Również na gruncie kodeksu karnego, a także kodeksu postępowania karnego ustawodawca stosuje ten termin. Przykładem może być art. 197 § 3 k.k, Ustawa z dnia 6 czerwca 1997 roku Kodeks Karny, Dz.U. z 1997 r. Nr 88, poz. 553 z późn. zm., art. 185a $\S 4$ k.p.k., a także art. 185a § 4 k.p.k., Ustawa z dnia 6 czerwca 1997 roku Kodeks Postępowania Karnego, Dz.U. z 1997 r. Nr 89, poz. 555 z późn. zm. Natomiast definicję dziecka można odnaleźć w Konwencji o prawach dziecka, zgodnie z którą dzieckiem jest każda istota ludzka w wieku poniżej 18 lat, chyba że zgodnie z prawem odnoszącym się do dziecka uzyska ono wcześniej pełnoletniość. W związku z tym zamienne stosowanie tych pojęć wydaje się w kontekście omawianego zagadnienia uzasadnione.

17 Dz.U. z 2008 r. Nr 220, poz. 1431.

18 Należy wskazać na niektóre postanowienia SN w przedmiotowej kwestii: postanowienie SN z dnia 1 października 1998 roku (sygn. I CKN 825/98); postanowienie SN 
przepisów zleca wykonanie czynności wysłuchania przez sąd, wykluczając przeprowadzenie jej przez na przykład biegłego psychologa. I w tym względzie zdania wyrażane w literaturze są podzielone — niektórzy autorzy ${ }^{19}$ kategorycznie opowiadają się za pośrednią formą zapoznawania się przez sąd z poglądami i życzeniami dziecka, które powinny być ustalone wyłącznie przez biegłego psychologa i następnie przekazane sądowi. Głównym argumentem przemawiającym za takim rozwiązaniem jest przede wszystkim dobro dziecka, konieczność ochrony tego dobra, tak aby zapobiec doznaniu przez nie urazów psychicznych związanych z koniecznością wielokrotnych rozmów z obcymi osobami na tematy związane z sytuacją kryzysową w rodzinie lub w związku z doznaną krzywdą ${ }^{20}$.

Jednak sposób sformułowania przepisów (art. $216^{1}$ k.p.c., art. 576 k.p.c.) świadczy o intencji ustawodawcy ustanowienia takiego instrumentu prawnego w postępowaniu sądowym, który polega na bezpośrednim kontakcie sędziego $\mathrm{z}$ dzieckiem. Zamysłem ustawodawcy najprawdopodobniej było zaakcentowanie rosnącej samodzielności dorastających dzieci, zwłaszcza w kontekście podejmowania decyzji i składania oświadczeń woli. Nie ulega wątpliwości, że z kodeksowego punktu widzenia wysłuchanie jest czynnością prawną, natomiast z psychologicznego jest to forma relacji miedzy dwiema osobami.

Wysłuchanie jest czynnością bardzo trudną dla sędziego, gdyż wiąże się z wieloma problemami, na przykład brakiem jasnych procedur prawnych ${ }^{21}$ czy brakiem wiedzy psychologicznej oraz pedagogicznej chociażby w podstawowym zakresie, tak aby móc rozpoznać cechy dziecka, które następnie pozwolą na dopasowanie do niego przebiegu samej czynności wysłuchania. Znajomość choćby podstaw psychologii rozwojowej daje szansę na właściwą interpretację i ocenę wypowiedzi dziecka. Te

z dnia 15 grudnia 1998 roku (I CKN 1122/98, OSNC $1999 \mathrm{nr} 6$, poz. 119).

19 W. Stojanowska, M. Kosek, Nowelizacja prawa rodzinnego na podstawie ustaw z 6 listopada 2008 r. i 10 czerwca 2010 r. Analiza. Wykładnia, Komentarz, Warszawa 2011.

20 J. Słyk, Aspekty prawne wystuchania dziecka w postępowaniu cywilnym, „Dziecko Krzywdzone. Teoria, Badania, Praktyka” 14, 2015, nr 4, s. 20.

21 Zróżnicowanie w zakresie warunków i sposobów rejestracji czynności wysłuchania, sposobu zdawania pytań oraz interpretacji odpowiedzi. Zob. M. Cieśliński, Praktyka sądowa $w$ zakresie wystuchania małoletnich świadków w postepowaniu cywilnym w kontekście idei przyjaznego wystuchania dziecka, Warszawa 2015. 
powody są głównymi źródłami ograniczeń gotowości sędziów do wykorzystania instytucji wysłuchania ${ }^{22}$, a przecież daje ono sędziemu ogromne walory poznawcze, na przykład poznanie małoletniego, rozpoznanie jego nastawienia do sytuacji, w jakiej się znalazł, skonfrontowanie własnych obserwacji z danymi, jakie już ma na temat dziecka, zestawienie stanowiska rodziców $\mathrm{z}$ bezpośrednimi informacjami uzyskanymi od dziecka - to wszystko umożliwia rozszerzenie perspektywy oceny sytuacji dziecka. Ten potencjał jednak pociąga za sobą także obowiązki, które spoczywają na organie. Zapewnienie dziecku bezpiecznych warunków, które sprzyjają swobodnej wypowiedzi, zagwarantowanie intymności w kontakcie z sędzią, wyjaśnienie dziecku roli, w jakiej występuje w postępowaniu oraz samej procedury wysłuchania, tak aby zmniejszyć jego niepokój przed sytuacją nieznaną i obciążającą go psychologicznie, to podstawowe założenia, które muszą być spełnione ${ }^{23}$. Jednak wymienione przesłanki muszą być w korelacji z gotowością dziecka do kontaktu z sędzią. Chęć do rozmowy z sędzią zależy od wielu czynników: relacji i więzi dziecka z rodzicami, udziału rodziców w życiu dziecka, rozumienia przez dziecko jego roli w postępowaniu, właściwości osobniczych dziecka $^{24}$, lecz także — a może nawet przede wszystkim — od spełnienia

22 Ograniczenie stosowania instytucji wysłuchania potwierdzają badania aktowe oraz jakościowe przeprowadzone przez Fundację Dajemy Dzieciom Siłę. Zob. A. Bąk, Bo sąd jest taki wazny" - doświadczenia dzieci uczestniczących w czynności wystuchania. Raport z badania jakościowego, „Dziecko Krzywdzone. Teoria, Badania, Praktyka" 14, 2015, nr 4, s. 82 n.; O. Trocha, Udziat dzieci w postepowaniu o ograniczenie władzy rodzicielskiej. Raport z badan aktowych, „Dziecko Krzywdzone. Teoria, Dadania, praktyka" 14, 2015, nr 4, s. 55 n.

23 Należy zaznaczyć, że wysłuchanie nie może zastępować innych czynności prawnych, zwłaszcza takich jak: badania psychologiczne, przesłuchanie świadków, mediacja.

24 Oczywiście są dzieci, które demonstrują gotowość do kontaktu z sędzią i wyrażania własnego zdania w sprawach ich dotyczących. Zob. A. Budzyńska, Wysłuchanie dziecka w postępowaniu cywilnym - perspektywa psychologiczna, „Dziecko Krzywdzone. Teoria, Badania, Praktyka" 14, 2015, nr 4, s. 42. W tym miejscu należy ustosunkować się do kwestii wieku dziecka, które uczestniczy w wysłuchaniu. Ustawodawca nie przewidział ograniczeń związanych z wiekiem małoletniego uczestniczącego w czynności wysłuchania. Podobna sytuacja dotyczy dzieci uczestniczących w charakterze świadków w postępowaniu karnym. Jednak zdania w tym zakresie nie są jednoznaczne. Wielu praktyków i badaczy problemu wyraża stanowisko, że dzieci przed ukończeniem czterech lat nie mają dostatecznych kompetencji intelektualnych oraz społeczno-emocjonalnych, 
warunków wynikających z regulacji prawnych ${ }^{25}$. Ich ocena oraz interpretacja stawia sędziego w niełatwej roli, gdyż w takich okolicznościach wiedza psychologiczna jest niezbędna.

Zarówno art. $216^{1} \S 1$ k.p.c., jak i art. $576 \S 2$ wskazują na trzy okoliczności, które muszą zostać spełnione, aby wysłuchanie dziecka było możliwe. Małoletni musi dysponować odpowiednim:

- rozwojem umysłowym,

- stanem zdrowia,

— stopniem dojrzałości.

W odniesieniu do uwzględnienia zdania dziecka (art. $216^{1} \S 2$ ) należy dodatkowo wziąć pod uwagę:

— okoliczności,

— rozsądne życzenia dziecka.

Rozwój umysłowy w psychologii oznacza stopień rozwoju intelektualnego, społecznego i emocjonalnego dziecka w odniesieniu do normy wiekowej. W omawianej regulacji rozwój umysłowy będzie dotyczył indywidualnych cech dziecka w trzech wymienionych obszarach funkcjonowania ${ }^{26}$. Wobec tego może zajść sytuacja, w której małoletni będzie bardzo dobrze rozwinięty intelektualnie, ale jego rozwój emocjonalny, społeczny będzie zakłócony, co może wpłynąć na utrudnione kontakty z sędzią, przejawiające się problemami w wypowiadaniu własnych ocen, potrzeb, przeżyć. O ile w postępowaniu karnym bardzo ważne są zdolności małoletniego świadka w postrzeganiu, zapamiętywaniu i odtwarzaniu zdarzeń, sytuacji, osób, o tyle w procedurze cywilnej umiejętności te mają drugorzędne znaczenie. W postępowaniu cywilnym to właśnie mowa czynna i bierna, która jest wykształcona na poziomie swobod-

aby składać zeznania. Zdaniem A. Czeredereckiej wystąpienie przed sądem mogłoby powodować „usztywnienie" małoletniego w wieku 12-15 lat w zakresie wyrażonej wobec sędziego opinii, a w konsekwencji skutkowałoby negatywnymi relacjami z rodzicami. Korzystanie z wysłuchania zdaniem autorki zalecane jest w odniesieniu do dzieci najstarszych w wieku 16-17 lat. Wnioski autorki wynikają z założenia, że wysłuchanie jest przeprowadzane w warunkach oficjalnego posiedzenia sądowego i braku kompetencji sędziego w zakresie postępowania z dziećmi. Ibidem, s. 30 n.

${ }^{25}$ Art. $216^{1}$ k.p.c., art. 576 k.p.c.

${ }^{26}$ M. Kielar-Turska, M. Bielecka-Pikul, Wczesne dzieciństwo, [w:] B. Harwas-Napierała, J. Trempała, Psychologia rozwoju człowieka. Charakterystyka okresów życia człowieka, Warszawa 2007, s. 47 n. 
nej komunikacji, warunkuje wyrażenie własnego stanowiska i jest niezbędnym atrybutem sprzyjającym wysłuchaniu; zdolność koncentracji, skupienie uwagi na rozmowie to również ważne elementy warunkujące poprawność wzajemnej relacji ${ }^{27}$. Należy też pamiętać o deficytach w rozwoju intelektualnym, które nie są jednoznacznym wyznacznikiem wykluczenia udziału dziecka w wysłuchaniu. Głębokość i jakość takich deficytów może skutkować koniecznością podjęcia konsultacji psychologicznych lub poprowadzeniem rozmowy w sposób dostosowany do indywidualnych potrzeb i możliwości małoletniego rozmówcy ${ }^{28}$.

Kolejnym elementem jest ocena stanu zdrowia psychicznego, która powinna uwzględniać nieprawidłowości nie tylko w obszarach upośledzenia umysłowego, zaburzeń o podłożu neurologicznym, zaburzeń zachowania i emocji oraz rozwoju psychicznego, lecz także te związane $z$ dolegliwościami somatycznymi ${ }^{29}$. Nieprawidłowości mogą być skutkiem czynników wewnątrzpochodnych oraz zewnętrznych niezwiązanych lub związanych bezpośrednio lub pośrednio z sytuacją rodzinną. Nieodpowiedni rozwój procesów poznawczych często jest elementem innych deficytów obejmujących pozostałe obszary osobowości. Zwykle $\mathrm{w}$ takich sytuacjach dziecko pozostaje pod opieką poradni zdrowia psychicznego, a w aktach sprawy znajduje się odpowiednia dokumentacja lekarska ${ }^{30}$. Nawet $\mathrm{w}$ takich wypadkach nie można jednak automatycznie wykluczać udziału dziecka w wysłuchaniu. Taka sytuacja wymaga każdorazowo indywidualnego podejścia i rozważenia, jakie problemy intelektualne, które nastręczają trudności w ocenie własnej sytuacji w rodzinie, dziecko reprezentuje, jak słabo wykształcone są u niego mechanizmy zaradcze, jak ocenia siebie i relacje z innymi oraz czy konsekwencje udziału w postępowaniu nie będą dla dziecka zbyt traumatyczne ${ }^{31}$.

27 Oczywiście są także inne cechy stanowiące o stopniu dojrzałości dziecka. Więcej zob. ibidem, s. 47-78; A. Czerederecka, Psychologiczne kryteria wystuchania dziecka w sprawach rodzinnych i opiekuńczych, „Rodzina i Prawo” 2010, nr 14-15, s. 27-33.

28 A. Budzyńska, op. cit., s. 43.

${ }^{29}$ Choroby somatyczne zdaniem lekarzy specjalistów powinny wykluczać dziecko $\mathrm{z}$ udziału w procedurach prawych.

30 Osobami kompetentnymi do rozpoznania określonych jednostek chorobowych, wskazania co do przebiegu leczenia są lekarze psychiatrzy lub neurolodzy dziecięcy.

31 A. Czerederecka, op. cit., s. 33-34. 
Stopień dojrzałości dziecka w kontekście wysłuchania to określony zespół cech, które sprawiają, że dziecko jest świadome własnych potrzeb i preferencji oraz zgłasza umiejętność i gotowość ich artykułowania. To również predyspozycje psychiczne, takie jak odporność na stres i trudne sytuacje, pozwalające poczuć się dziecku autonomicznie i niezależnie od ocen innych. Okres adolescencji ${ }^{32}$ młodzieńczej to czas utrwalania się tożsamości małoletniego, który ma umiejętność rozpoznawania intencji innych osób, rozumie swoją rolę w postępowaniu, choć nadal doskonali stabilizację emocjonalną, rozwój uczuć wyższych i pracuje nad swoją tożsamością.

Mając na uwadze wyszczególnione czynniki i zależności zachodzące między nimi, można ustosunkować się do wskazanych przez ustawodawcę warunków wysłuchania. Pojawiają się w tym miejscu pytania, które niejednokrotnie powielają się w literaturze, a na które trudno znaleźć jednoznaczne i proste odpowiedzi. Czy sąd dysponuje wystarczającymi danymi, aby rozważyć, czy istnieją podstawy do przeprowadzenia czynności wysłuchania? W jaki sposób sędzia ma ocenić stan zdrowia i dojrzałość dziecka ${ }^{33}$, które ma być poddane wysłuchaniu? Czy ma wezwać dziecko na rozmowę wstępną i dokonać oceny, a może wystarczy rozmowa $\mathrm{z}$ rodzicami? ${ }^{34}$

Sędzia, dysponując wiedzą, doświadczeniem życiowym i zawodowym, nie zawsze jest w stanie jednoznacznie rozstrzygnąć, czy zachodzą kodeksowe warunki przeprowadzenia czynności wysłuchania. Może posiłkować się zdaniem rodziców odnośnie do stanu dziecka, choć nie zawsze jest to opinia obiektywna, tym bardziej jeśli rodzice uwikłani są w trwające postępowanie. Opinia szkoły, przedszkola oraz dokumenty znajdujące się w aktach sprawy to również dyskusyjne materiały. Wychowawca co prawda dysponuje wiedzą wynikającą z obserwacji dziecka w różnych kontekstach sytuacyjnych, lecz jest ona ograniczona jedynie do szkoły ${ }^{35}$. Dokumenty znajdujące się w materiałach sprawy

32 Zwany także wiekiem młodzieńczym (lub fazą motyla) obejmuje 16/17-20/21 rok życia. Charakteryzuje się osiąganiem dojrzałości we wszystkich sferach rozwoju. Zob. I. Obuchowska, Adolescencja, [w:] B. Harwas-Napierała, J. Trempała, op. cit., s. 163 n.

33 Sędzia dziecka nie widział, nie miał wcześniej z nim kontaktu.

34 Więcej pytań stawia A. Czerederecka, op. cit., s. 37.

35 Zwolennikiem takiego rozwiązania jest J. Gudowski. 
niejednokrotnie są natomiast dostarczane przez rodziców i najczęściej po ich sprawdzeniu zawierają jednostronne wypowiedzi potwierdzające ich tezy. Wstępna rozmowa $\mathrm{z}$ dzieckiem również nie do końca jest dobrym przedsięwzięciem, gdyż może doprowadzić do powzięcia zbyt pochopnych wniosków, które w konsekwencji mogą skutkować podjęciem błędnych decyzji, a dziecko mogą narazić na uraz psychiczny. W takich okolicznościach humanitarne założenia podmiotowego traktowania dziecka nie spełniłyby swojego celu, a jedynie doprowadziły do efektów sprzecznych z jego dobrem ${ }^{36}$.

Mając na uwadze poczynione refleksje, należy ponowić pytanie, kto i przy pomocy jakich narzędzi jest w stanie ocenić zasadność przeprowadzenia czynności wysłuchania dziecka? W tym kontekście odpowiedź nie powinna nastręczać większych trudności - powinny to być osoby do tego upoważnione i przygotowane, dysponujące wiedzą specjalistyczną i działające na zlecenie sądu, psychologowie zajmujący się przede wszystkim problematyką dzieci i młodzieży, których udział w wykonaniu opinii jest obligatoryjny, oraz opcjonalnie, w zależności od potrzeb, pedagodzy oraz lekarze, na przykład psychiatrzy lub neurolodzy ${ }^{37}$. Taka opinia powinna być przygotowana na podstawie analizy akt sprawy sądowej, badań dziecka (obejmujących między innymi obserwację, rozmowę, testy psychologiczne) oraz wywiadu z rodzicami. Takie rozwiązanie, choć jest uzasadnione, sprawia jednak trudności natury praktycznej, zwłaszcza w kontekście długiego okresu oczekiwania na wydanie opinii,

${ }^{36}$ A. Czerederecka, op. cit., s. 38. Można rozważyć jeszcze wywiad środowiskowy, choć informacje uzyskane na jego podstawie obciążone są pewnym ryzykiem. Zwykle przeprowadzany jest przez osobę z przygotowaniem pedagogicznym, jednak na podstawie jednorazowej wizyty, w ramach której prowadzący rozmowę może „wybadać”, jakie są deklaracje dziecka, jego motywacja, zachowanie. Zob. więcej W. Stojanowska, Status dziecka $w$ zakresie jego uczestnictwa w postępowaniu sadowym, [w:] J. Stochmiałek, Pedagogika wobec kryzysów życiowych, Warszawa 1998, s. 105-107; W Stojanowska, Dziecko w postępowaniu sqdowym, „Jurysta” 1997, nr 5, s. 50-61.

37 Za takim rozwiązaniem opowiadają się m.in. W. Stojanowska, Dziecko w postępowaniu..., s. 61; R. Zegadło, Dziecko w postępowaniu cywilnym. Europejska konwencja o wykonywaniu praw dziecka a prawo polskie, Materiały szkoleniowe Krajowej Szkoły Sądownictwa i Prokuratury Będlewo 2008, cyt. za: A. Czerederecka, op. cit., s. 39; T. Smyczyński, Legislacyjne podstawy ochrony dziecka, Warszawa 2003, cyt. za: A. Czerederecka, op. cit., s. 39; H. Ciepła, Nowelizacje kodeksu rodzinnego i opiekuńczego, Warszawa 2010, s. 22. 
oraz poniesionych kosztów. Jednak dobro dziecka i jego prawa w tym względzie są najważniejsze, więc uzasadnione jest odczekanie nawet kilku miesięcy, aby uzyskać wszechstronną opinię specjalistów ${ }^{38}$. Opinia biegłych ${ }^{39}$ mogłaby znacząco ułatwić postępowanie sądu, jednak musiałaby zostać wydana przed podjęciem decyzji odnoszącej się do czynności wysłuchania $^{40}$.

Analizując kolejne elementy „okoliczności”, o których mowa w przepisach, można potraktować je jako tak zwane czynniki sytuacyjne, które powinny być uwzględnione na równi z rozsądnymi życzeniami dziecka przy planowaniu czynności wysłuchania. W ramach tak zwanych czynników sytuacyjnych można wskazać na: wpływ sytuacji rodzinnej na postawę i treść wypowiedzi udzielanej przez dziecko oraz okoliczności, miejsce i sposób wysłuchania. Należy także mieć na uwadze obiektywne możliwości przy rozpatrywaniu oczekiwań dziecka ${ }^{41}$.

Uwzględniając wpływ sytuacji rodzinnej na dziecko, na przykład kiedy dochodzi do nadużywania praw lub zaniedbywania obowiązków rodzicielskich, można wnioskować, że przedmiotem prowadzonego postępowania są sprawy o ograniczenie lub pozbawienie władzy rodzicielskiej. Źródłem takiego stanu rzeczy często bywają przejawy patologii społecznej lub/i psychicznej. Konsekwencją takiej niewydolności rodzicielskiej, wychowawczej jest niezaspokajanie podstawowych potrzeb psychicznych i fizycznych dziecka, czyli zakłócanie prawidłowych warunków jego rozwoju. Dzieci wychowujące się w takich dysfunkcyjnych rodzinach są nieufne wobec przedstawicieli wszelkich instytucji, wstydzą się, czują się współwinne zaistniałej sytuacji, obawiając się, że zostaną odebra-

38 Pojawiły się także głosy, aby dziecko swoje poglądy wyraziło za pośrednictwem biegłych z opiniodawczych zespołów sądowych specjalistów (zastąpiły one w 2016 roku rodzinne ośrodki diagnostyczno-konsultacyjne na mocy ustawy o opiniodawczych zespołach sądowych specjalistów z 5 sierpnia 2015 roku, Dz.U. z 2015 r. poz. 1418). Zob. pogląd wyrażony w 1999 roku przez SN w postanowieniu z dnia 15 grudnia 1998 roku (I CKN 1122/98, OSNC 1999 nr 6, poz. 119); J. Słyk, op. cit., s. 24.

$39 \mathrm{~W}$ razie potrzeby ci sami biegli mogliby wydać opinię uzupełniającą, rozszerzając badania i wypowiadając się szerzej na temat sytuacji rodzinnej dziecka.

${ }^{40}$ A. Czerederecka, op. cit., s. 40.

41 Na przykład nie wystarczy, że dziecko chce pozostawać pod opieką rodziców, muszą oni mieć do tego odpowiednie i wystarczające kompetencje wychowawcze oraz muszą chcieć zajmować się dzieckiem. 
ne rodzicom i umieszczone w placówce opiekuńczej. Rozmowa w trakcie wysłuchania, mając na uwadze te okoliczności, wymaga analizy zachowania dziecka zwłaszcza w kontekście bagatelizowania całej sytuacji w celu ochrony rodziców lub opiekunów. Sytuacja może się inaczej kształtować, jeśli opiekę sprawuje jeden z rodziców lub dziecko ma innych opiekunów, kiedy czuje się bezpiecznie w nowym środowisku, jego odpowiedzi mogą być nacechowane negatywnymi doświadczeniami, które przybiorą postać wręcz przerysowanych zdarzeń. Elementy nagromadzonego stresu, frustracji również mogą ujawniać się w wypowiedziach małoletniego ${ }^{42}$.

Rozważając warunki wysłuchania, warto skorzystać z bogatego doświadczenia dotyczącego przesłuchania dziecka w sprawach karnych ${ }^{43}$. Mimo zasadniczych różnic, jakie związane są z charakterem postępowania cywilnego i karnego, jak również odmiennością wykonywanych czynności (przesłuchanie, wysłuchanie), wskazówki dotyczące przesłuchania, które są elementami taktyki kryminalistycznej, można odnieść do wysłuchania dziecka. Należy brać pod uwagę takie okoliczności, jak: miejsce i czas przeprowadzenia wysłuchania, osoby obecne podczas rozmowy, sposób wysłuchania i rejestrowania czynności.

Wybór czasu i miejsca przesłuchania to niezwykle istotny element, który należy uwzględnić przed przystąpieniem do wysłuchania. Na początkowym etapie prowadzonego postępowania kontakt z dzieckiem może być przedwczesny, gdyż sędzia najprawdopodobniej nie będzie miał pełnego obrazu sytuacji, natomiast spotkanie z dzieckiem na zakończenie prowadzonej sprawy również nie jest dostatecznie dobrym posunięciem, gdyż małoletni może obwiniać się o rezultat wyroku, jaki zapadł. Analizowane unormowania nie określają precyzyjnie sposobu i formy przeprowadzenia wysłuchania dziecka. Jedyne wskazówki w tym zakresie dotyczą miejsca, w którym ma być przeprowadzone wysłuchanie. Zgodnie z art. 576 § 2

42 Sytuacje rodzinne, w których znajduje się małoletni, mogą być zróżnicowane, o czym pisze m.in. A. Czerederecka, op. cit., s. 34-36.

43 Więcej zob. E. Gruza, Ocena wiarygodności zeznań świadka w prawie karnym. Problematyka kryminalistyczna, Kraków 2003; V. Kwiatkowska-Darul, Przesłuchanie dziecka, Kraków 2001; J. Sokołowska, Dziecko jako świadek, Warszawa 1959; A. Gadomska-Radel, Przestuchanie dziecka jako ofiary $i$ świadka przestępstwa w postępowaniu karnym, Warszawa 2014. 
k.p.c. czynność powinna odbywać się poza salą posiedzeń sądowych ${ }^{44}$. Wykorzystane do tego celu mogą być pokoje specjalnie przeznaczone i przystosowane do przesłuchań, które mogą znajdować się w siedzibie sądu lub poza nim ${ }^{45}$. Przepis ten jest wyrazem dbałości ustawodawcy w zakresie ochrony dobra dziecka i przeciwdziałania potencjalnym urazom związanym z dokonywanymi czynnościami ${ }^{46}$.

Przepisy nie określają, czy dziecko powinno być wysłuchane przez cały skład orzekający w danej sprawie, czy też wyznaczony ze składu jeden sędzia będzie tą osobą, która poprowadzi czynność. Brak jednoznacznej regulacji przemawia raczej na rzecz zaangażowania całego składu sędziowskiego ${ }^{47}$. Jednak $\mathrm{w}$ literaturze pojawia się w pełni uzasadniony postulat, aby wysłuchanie przeprowadzał jeden sędzia, natomiast pozostali powinni mieć możliwość obserwacji czynności lub ewentualność odsłuchania nagrania ${ }^{48}$. Jednoosobowe prowadzenie wysłuchania wyklucza obecność innych osób, stron/uczestników postępowania i ich pełnomocników. Opcjonalnie natomiast dopuszczalny jest udział biegłego psycho$\operatorname{loga}^{49}$. Przepisy dookreślają, że sędzia sporządza notatkę z wysłuchania ${ }^{50}$. Sposób utrwalania przebiegu wysłuchania jest przedmiotem wielu rozwa-

44 Brakuje w zapisie kodeksowym bliższych informacji dotyczących warunków przeprowadzenia wysłuchania.

${ }^{45}$ Zdaniem A. Czeredereckiej pomieszczenie, w którym przeprowadza się wysłuchanie dziecka, powinno odpowiadać warunkom przyjaznego pokoju przesłuchań. Paragraf 154 Regulaminu urzędowania sądów powszechnych z dnia 23 grudnia 2015 roku zawiera unormowania dotyczące miejsca przeprowadzenia wysłuchania. Rozporządzenie Ministra Sprawiedliwości, Dz.U. z 2015 r. poz. 2316.

46 J. Słyk, op. cit., s. 25.

47 M. Cieśliński, Wystuchanie dziecka w procesie cywilnym, „Przegląd Sądowy” 2012, nr 6, s. 65 n.

${ }^{48}$ Kwestia dokumentacji czynności wysłuchania jest dość kontrowersyjna i pojawiają się w tym względzie różne głosy.

49 Zdarza się tak zwane wysłuchanie pośrednie, realizowane nie przez sędziego, a przez psychologa lub zespół biegłych lub kuratora sądowego. Forma ta jest akceptowana przez część środowiska psychologów jako bezpieczniejsza dla małoletnich. Pojawiają się jednak wątpliwości, czy jest to wysłuchanie, czy może jednak badanie sądowo-psychologiczne lub badanie przez biegłych; jaką w takiej sytuacji przyjąć formę dokumentowania, przez analogię notatkę, czy może należy spisać protokół. Zob. A. Budzyńska, op. cit., s. 46.

${ }^{50}$ Regulamin urzędowania sądów w $\S 154$ ust. 2 przewiduje sporządzenie notatki urzędowej z czynności wysłuchania. Art. 157 § 3 k.p.c. również taką formę zakłada. 
żań w literaturze i pojawiają się w tym względzie różne propozycje. J. Gudowski ${ }^{51}$ na przykład dopuszcza nagranie rozmowy, zastępując czynność protokołowania, która może być dla dziecka dość krępująca i obciążająca. Zdaniem A. Czeredereckiej ${ }^{52} \mathrm{w}$ przypadku nagrywania przebiegu wysłuchania konieczne jest uzyskanie zgody dziecka. M. Cieśliński ${ }^{53}$ natomiast prezentuje pogląd, zgodnie z którym wysłuchanie odbywające się $\mathrm{w}$ ramach posiedzenia niejawnego powinno być dokumentowane $\mathrm{w}$ formie notatki i jest to wystarczający stan, gdyż przyjęcie odmiennego kształtu dokumentacji skutkowałoby możliwością zapoznania się z tymi materiałami, złożonymi do akt sprawy, przez uczestników postępowania ${ }^{54}$.

Osoba prowadząca rozmowę ma niełatwe zadanie, gdyż musi nawiązać kontakt z wysłuchiwanym dzieckiem, mając jednocześnie na uwadze zasady sprzyjające konstruktywnemu prowadzeniu rozmowy. Cywilne ubranie, swobodna postawa, zainteresowanie dzieckiem i rozmową oraz zrozumiałe i proste pytania to priorytety podczas prowadzenia wysłuchania. Dopasowanie przebiegu czynności wysłuchania do małoletniego uzależnione jest od zdolności koncentracji dziecka, jego umiejętności językowych, stanu emocjonalnego, stąd wynika konieczność wykazania cierpliwości, spokoju i akceptacji wobec dziecka ${ }^{55}$. Istotne znaczenie ma merytoryczne przygotowanie sędziego z psychologii, ewentualnie pedagogiki, by móc dostosować rozmowę i zadawane pytania do stopnia dojrzałości i rozwoju umysłowego dziecka oraz aby umieć odpowiednio zinterpretować uzyskane odpowiedzi ${ }^{56}$.

Mimo wielu uwag, niekiedy nawet krytycznych, instytucja wysłuchania jest uzasadniona, gdyż sprzyja swobodnemu wyrażaniu przez dziecko stanowiska w kwestiach jego dotyczących, przy jednoczesnym umożliwieniu sędziemu pozyskania informacji przydatnych do rozstrzy-

51 J. Gudowski, [w:] T. Ereciński, Kodeks postepowania cywilnego. Komentarz. Postepowanie rozpoznawcze, Warszawa 2012, s. 155 n.

52 A. Czerederecka, op. cit., s. 42.

53 M. Cieśliński, op. cit., s. 67 n.

54 Odmienne zdanie prezentuje J. Zajączkowska, Głos dziecka na wokandzie o instytucji wystuchania małoletniego, „Palestra” 58, 2013, nr 7-8, s. 64, palestra.pl/ upload/14/25/46/1425468632_.pdf (dostęp: 1.10.2017).

55 A. Czerederecka, op. cit., s. 42; A. Budzyńska, op. cit., s. 51.

56 Dziecko może odmówić udziału w czynności wysłuchania, nie powinno być do niej w jakikolwiek sposób zmuszane; zob. J. Słyk, op. cit., s. 27. 
gnięcia prowadzonego postępowania. Właściwe przeprowadzenie omawianej czynności daje szansę ochrony dziecka, nie tylko w kontekście wydania wyroku zgodnego z jego interesem, lecz także sygnalizując, że jego potrzeby są ważne i ma prawo głośno je wyrażać 57 .

Konkludując, warto w skrócie wskazać etapy czynności wysłuchania w kontekście ochrony psychologicznej dziecka w ramach trwającej procedury cywilnej. Podziału można dokonać, wyodrębniając trzy etapy ${ }^{58}$.

Etap wstępny, zanim dojdzie do kontaktu sędziego z dzieckiem, obejmuje działania związane z

- zapoznaniem się przez sędziego z ewentualnymi opiniami specjalistów na temat dziecka, jeśli biegli lekarze mieli wcześniej kontakt z dzieckiem;

— możliwością przeprowadzenia konsultacji psychologicznej pod kątem ustalenia możliwości uczestnictwa dziecka w czynności wysłuchania. Wskazówki biegłych mają dookreślać sposób realizacji czynności wysłuchania w dopasowaniu do indywidualnych potrzeb małoletniego;

— oceną dokonaną przez sędziego, czy możliwy jest udział dziecka w wysłuchaniu;

- ustaleniem odpowiedniego terminu, w którym przesłuchanie zostanie przeprowadzone;

— doborem odpowiedniego miejsca przeprowadzenia czynności wysłuchania;

— poinformowaniem i przygotowaniem rodziców dziecka do wysłuchania. Informacja dotyczy przede wszystkim celu przeprowadzenia takiej właśnie czynności oraz zasad jej realizacji. Przygotowanie natomiast będzie się odnosić do uwrażliwienia rodziców na przeżycia dziecka związane z wysłuchaniem, zobowiązania rodziców do niewpływania na to, co dziecko będzie mówić, oraz nierozpytywania dziecka o przebieg czynności.

57 A. Budzyńska, op. cit., s. 52.

58 Podobny podział zaproponowały autorki artykułu w ramach publikacji uwzględniającej procedurę karną; zob. S. Skubisz-Ślusarczyk, I. Zieniewicz, Aspekty prawno-kryminalistyczne oraz psychologiczne ochrony zdrowia małoletniego świadka przed wptywem negatywnych czynników procesowych, [w:] Problematyka ochrony życia i zdrowia ludzkiego w prawie karnym, red. P. Góralski, Warszawa 2016, s. 263-301. Podział taki został także zaproponowany przez A. Budzyńską; zob. eadem, op. cit., s. 49-50. 
Etap drugi, w ramach którego dochodzi do bezpośredniego kontaktu sędziego z małoletnim, obejmuje:

- odpowiednie nastawienie i przygotowanie sędziego, na które będzie się składać wyjaśnienie dziecku celu i zasad rozmowy. Dziecko powinno mieć poczucie swobody wypowiedzi, jej poufności oraz indywidualności;

— rozpoczęcie rozmowy na tematy luźne, niezwiązane z trwającym postępowaniem. Taki start ma zapewnić dziecku komfort psychiczny, rozładować napięcie emocjonalne i spowodować, że obie strony nawiążą kontakt;

- możliwość zadawania pytań przez dziecko. Pytania mogą zawierać lęki i obawy o przyszłość rodziny i jego samego. Z psychologicznego punktu widzenia odpowiedź na nie jest bardzo istotna - dziecko nie powinno zakończyć czynności wysłuchania z przekonaniem, że teraz stanie się coś złego;

— podziękowanie dziecku za udział w czynności i docenienie jego odwagi i chęci uczestnictwa w czynności wysłuchania.

Etap trzeci następuje po zakończeniu spotkania z dzieckiem i obejmuje działania związane z:

— analizą wypowiedzi dziecka. Badanie wyrażonych w rozmowie przez dziecko potrzeb i preferencji;

- ewentualną konsultacją z psychologiem celem interpretacji materiału uzyskanego w trakcie wysłuchania;

- sporządzeniem notatki, w której powinny być odnotowane podstawowe kwestie: kiedy, o której godzinie i w jakich warunkach przeprowadzono wysłuchanie, oraz zasadnicze tezy rozmowy wraz z wnioskami,

- przygotowaniem wniosków z rozmowy z dzieckiem, które będą mogły być przedstawione na posiedzeniu sądu;

- przygotowaniem zaleceń dotyczących dalszej opieki psychologicznej, jeśli taka jest prowadzona, lub rozważenia kwestii jej wprowadzenia. Zalecenia takie sędzia może proponować po wcześniejszej konsultacji z psychologiem.

Dla porównania ochrony psychologicznej realizowanej podczas czynności wysłuchania dziecka w postępowaniu cywilnym z przedstawionym zakresem warto wskazać, jak podczas realizacji zakładanych czynności w postępowaniu karnym kształtuje się omawiana ochrona. Ni- 
niejszy podział odwołuje się do dość długiego okresu, ponieważ obejmuje okoliczności przed rozpoczęciem, w trakcie trwania i po zakończeniu postępowania karnego.

Etap wstępny ochrony psychologicznej małoletniego przed rozpoczęciem postępowania karnego obejmuje:

- edukację dziecka, w ramach której przekazywane są informacje na temat składania zeznań, przebiegu postępowania, przysługujących praw i obowiązków, przyjęcie takiej postawy ma sprzyjać złagodzeniu negatywnych skutków emocjonalnych;

- omówienie z dzieckiem lęków przed nieznanym miejscem, w którym się znajdzie, wskazanie na nową sytuację, która może napawać strachem i niepewnością;

— wskazywanie i wypracowywanie z dzieckiem metod radzenia sobie ze stresem i trudną sytuacją;

- przećwiczenie umiejętności rozumienia i udzielania odpowiedzi na zadane pytania, zgodnie z zasadą mówienia prawdy.

Rola psychologa we wskazanych czynnościach jest nieoceniona, jednak nie ogranicza się tylko do małoletnich, także rodzice powinni zostać przygotowani do dalszych działań, jakie będą podejmowane w ramach prowadzonego postępowania z udziałem dziecka. Spotkania z rodzicami mogą dotyczyć:

— przekazania wiedzy dotyczącej przebiegu postępowania karnego i procedury przesłuchania;

— uwrażliwienia bliskich na przeżycia dziecka związane z trwającymi procedurami prawnymi;

- efektywnego wspierania dzieci w życiu codziennym,

- wskazania miejsc, w których może zostać udzielona dodatkowa pomoc psychologiczna ${ }^{59}$.

Etap przedwstępny ochrony psychologicznej małoletniego w trakcie prowadzonego postępowania karnego obejmuje sferę działań, które poprzedzają bezpośredni kontakt z dzieckiem. W tym czasie podejmowane są czynności mające na celu:

59 Specjalista może spotkać się z rodziną w Centrum Pomocy Dzieciom. Terapeutyczna praca może być prowadzona indywidualnie wobec każdego członka rodziny lub obejmować całą rodzinę; http://wymiarsprawiedliwosci.fdn.pl/ (dostęp: 10.10.2017). 
- analizę dokumentów zawartych w aktach sprawy, uwzględniających także materiały dotyczące małoletniego;

— wybór odpowiedniego miejsca przesłuchania;

- zapewnienie odpowiednich pomocy, niezbędnych do diagnozy;

— zakreślenie obszaru obejmującego najistotniejsze zagadnienia, które będą poruszane podczas czynności;

- ustalenie współpracy między osobami przesłuchującymi (sędzia/ prokurator, biegły, psycholog).

W kolejnym etapie dochodzi do nawiązania kontaktu z dzieckiem, w jego ramach mieści się:

- zapoznanie z dzieckiem, polegające na przedstawieniu się;

- nawiązanie wzajemnego kontaktu poprzez poznanie z miejscem, w którym rozmowa będzie prowadzona, wyjaśnienie jej celu i przedmiotu;

- omówienie kwestii pozostania na sali rodzica/opiekuna bądź wskazanie, gdzie dorosły będzie oczekiwał na dziecko,

- wstępne zorientowanie się co do wiadomości dziecka na temat przedmiotu sprawy;

- eliminowanie stresu, który towarzyszy dziecku na każdym etapie prowadzonego postępowania, a który może spotęgować konieczność spotkania oko w oko z oskarżonym, zmiana obrońcy, nieprzewidziane opóźnienia czy odroczenia, a także zabranie dziecka z domu i umieszczenie poza nim oraz brak odpowiedniego przygotowania do roli na przykład świadka.

Po zakończeniu postępowania działania, które zostały zainicjowane na wstępie, są kontynuowane w celu dalszego zapewnienia niezbędnej ochrony psychologicznej. Obejmują one:

- pracę z objawami wynikającymi z doznanej krzywdy oraz udziału w procedurach,

- przywrócenie pozytywnego spojrzenia na świat i dorosłych;

- odbudowania poczucia własnej wartości, kontroli;

— nabycie umiejętności wyrażania własnych uczuć i potrzeb ${ }^{60}$.

Psycholog pracujący z dzieckiem na każdym etapie trwającego postępowania wskazuje na potrzebę wsparcia i zaangażowania rodziców,

60 S. Skubisz-Ślusarczyk, I. Zieniewicz, op. cit., s. 263-301. 
tak aby pomoc była skuteczna i efektywna w stosunku do wszystkich, którzy znaleźli się w trudnej sytuacji psychologicznej. Warunkiem prawidłowej ochrony małoletnich jest zaoferowanie profesjonalnej pomocy, która może rozpocząć się od zaangażowania psychologa interwencyjnego i powinna być kontynuowana podczas trwania postępowania oraz po jego zakończeniu.

Mimo wskazania podobieństw w odniesieniu do proponowanej i realizowanej ochrony psychologicznej trzeba mieć na uwadze istotne różnice między wysłuchaniem dziecka a przeprowadzeniem dowodu z przesłuchania małoletniego świadka. Celem przesłuchania jest uzyskanie relacji o faktach, natomiast wysłuchanie ukierunkowane jest na przedstawienie ocen ${ }^{61}$. W przeciwieństwie do przesłuchania świadka wysłuchanie nie jest określane jako dowód, co poniekąd powoduje, że nie obowiązują sformalizowane zasady prowadzenia postępowania dowodowego. Jednak funkcja wysłuchania jest bardzo podobna do dowodu, w tym dowodu z przesłuchania świadka, gdyż służy zebraniu przez sąd wiadomości o faktach wchodzących w skład podstawy faktycznej sprawy ${ }^{62}$.

Mając to na uwadze oraz kończąc rozważania stricte teoretyczne, można pokusić się o sformułowanie pewnych wniosków i sugestii w odniesieniu do czynności wysłuchania. Wnioski dotyczą przede wszystkim obaw sędziów — które dość często w literaturze są eksponowane, ale sygnalizują je również praktycy — o to, że kontakt z dzieckiem będzie utrudniony ze względu na brak z ich strony dostatecznej wiedzy psychologicznej, która pozwoliłaby na wyrobienie pewnego warsztatu pracy z małoletnim. Obawy pojawiają się także w odniesieniu do niejasnych i niepełnych przepisów prawnych, gdzie brak odpowiednich regulacji może doprowadzić do eskalacji roszczeń ze strony uczestników postępowania. Lęk dotyczy również kwestii odpowiedniego zaplecza w postaci zabezpieczenia stosownych warunków do rozmowy z dzieckiem ${ }^{63}$. Sugestie natomiast to organizowanie i odbywanie przez sędziów szkoleń, tak aby znane im były podstawowe zasady psychologii dziecka oraz podstawy pedagogiki. Niewątpliwie do-

61 M. Cieśliński, op. cit., s. 68-72.

62 J. Słyk, op. cit., s. 24.

63 Sędziowie wyrazili między innymi wskazane obawy w rozmowie z A. Budzyńską; zob. eadem, op. cit., s. 39. 
brym rozwiązaniem jest przygotowanie odpowiednich kampanii społecznych promujących upodmiotowienie dzieci w postępowaniach, tak aby w bezpiecznych warunkach mogły wyrażać własne potrzeby ${ }^{64}$.

\section{III}

Dla zobrazowania treści merytorycznych warto przytoczyć wyniki badań aktowych podejmowanych $\mathrm{w}$ okresie kilku ostatnich lat w odniesieniu do instytucji wysłuchania i przesłuchania.

Przedmiotem badan ${ }^{65}$ prowadzonych w Instytucie Wymiaru Sprawiedliwości były sprawy o pozbawienie władzy rodzicielskiej, w których przeprowadzono dowód z opinii rodzinnego ośrodka diagnostyczno-konsultacyjnego ${ }^{66}$, zakończone prawomocnie w 2011 i 2012 roku. Badanie objęło 96 spraw z całej Polski. Ustalono, że czynność wysłuchania dziecka została przeprowadzona tylko w 7 postępowaniach. Podczas analizy

64 Kampanie Fundacji Dzieci Niczyje (zmiana nazwy 11 maja 2016 roku na Fundacja Dajemy Dzieciom Siłę): „Dziecko — świadek szczególnej troski” (I edycja) - Celem kampanii było zwiększenie wrażliwości profesjonalistów uczestniczących $\mathrm{w}$ interwencji prawnej oraz pomagającym dzieciom ofiarom przestępstw (sędziów, prokuratorów, policjantów, psychologów biegłych sądowych) na specyficzną sytuację dziecka; w postępowaniu karnym oraz podniesienie ich kompetencji związanych z przesłuchiwaniem dziecka. http://fdn.pl/dziecko-swiadek-szczegolnej-troski-i-edycja (dostęp: 1.10.2017). „Dziecko — świadek szczególnej troski” (II edycja). Cel kampanii: oprócz kontynuacji osiągnięć poprzedniej kampanii położono nacisk na wszechstronne przygotowanie dziecka do wystąpienia w roli świadka, obejmując uświadamianie potrzeby pomocy nie tylko w trakcie procedur prawnych, lecz także przed nimi i po ich zakończeniu i to zarówno wśród profesjonalistów, jak i rodziców i opiekunów, http:// fdn.pl/dziecko-swiadek-szczegolnej-troski-ii-edycja (dostęp: 1.10.2017). „Dziecko — świadek szczególnej troski” (III edycja) — cel kampanii: hasło „Będę przesłuchany/a” miało na celu podkreślenie podmiotowości dziecka świadka i jego prawa do szczególnej ochrony w trudnych sytuacjach związanych z uczestniczeniem w procedurach karnych, http://fdn.pl/dziecko-swiadek-szczegolnej-troski-iii-edycja (dostęp: 1.10.2017).

65 E. Holewińska-Łapińska, Orzecznictwo $w$ sprawach o pozbawienie władzy rodzicielskiej, „Prawo w Działaniu. Sprawy cywilne” 14, 2013, s. 27-76, http://docplayer.pl/21102761-Orzecznictwo-w-sprawach-o-pozbawienie-wladzy-rodzicielskiej.html (dostęp: 10.10.2017).

66 Od 2016 roku funkcjonują opiniodawcze zespoły sądowych specjalistów. 
ustalono, że życzenia i preferencje dzieci zostały określone i wyartykułowane w opinii rodzinnego ośrodka diagnosyczno-konsultacyjnego.

Sprawy o ograniczenie i pozbawienie władzy rodzicielskiej były przedmiotem analizy I. Długoszewskiej ${ }^{67}$. Autorka poddała badaniu trzysta akt spraw. Wysłuchanie dziecka miało miejsce w 16 postępowaniach dotyczących ograniczenia władzy rodzicielskiej i w 2 odnoszących się do pobawienia władzy rodzicielskiej. Dowód z opinii rodzinnego ośrodka diagnostyczno-konsultacyjnego ${ }^{68}$ został przeprowadzony w 66 postępowaniach.

Natomiast J. Słyk ${ }^{69}$ prowadził analizę akt spraw w Instytucie Wymiaru Sprawiedliwości w odniesieniu do postępowań dotyczących rozstrzygnięcia sądu opiekuńczego o istotnej sprawie dziecka w sytuacji braku porozumienia rodziców. Badania objęły 166 akt spraw zakończonych prawomocnie w 2011 roku. Jedynie w 12 postępowaniach przeprowadzono wysłuchanie dziecka, a tylko w 5 sąd posiłkował się opinią rodzinnego ośrodka diagnostyczno-konsultacyjnego. J. Słyk ${ }^{70}$ podjął także analizę spraw dotyczących zezwolenia na dokonanie czynności przekraczających zakres zwykłego zarządu majątkiem dziecka. Wśród 200 wziętych pod uwagę postępowań tylko w 22 przypadkach sąd wysłuchał i zapoznał się ze stanowiskiem dziecka. Czynność ta została przeprowadzona w trakcie rozprawy, a nie w sposób przewidziany w art. 576 $\S 2$ k.p.c.

Należy także nadmienić, że Fundacja Dzieci Niczyje w latach 20152016 również przeprowadziła badania aktowe dotyczące udziału małoletnich w postępowaniu o ograniczenie władzy rodzicielskiej ${ }^{71}$. Celem

${ }^{67}$ I. Długoszewska, Przestanki oraz skutki ograniczenia i pozbawiania władzy rodzicielskiej, Warszawa 2012, s. 283-351.

68 Od 2016 roku funkcjonują opiniodawcze zespoły sądowych specjalistów.

69 J. Słyk, Rozstrzyganie o istotnych sprawach dziecka w przypadku braku porozumienia rodziców, „Prawo w Działaniu. Sprawy Cywilne” 14, 2013, s. 77-120, https:// www.iws.org.pl/.../Rozstrzyganie\%20o\%20istotnych\%20sprawach\%20dziecka (dostęp: 10.10.2017).

70 J. Słyk, Orzekanie w sprawach o zezwolenie na dokonanie czynności przekraczającej zakres zwyktego zarządu majątkiem dziecka, Warszawa 2014, s. 25-74, www. iws.org.pl/raporty-1 (dostęp: 10.10.2017).

${ }^{71}$ Badania były częścią projektu „Dajemy dzieciom siłę! — prawa dzieci w procedurach prawnych" realizowanego w ramach programu Obywatele dla Demokracji, finansowanego z funduszy EOG.

Nowa Kodyfikacja Prawa Karnego 50, 2018

(C) for this edition by CNS 
badań było zweryfikowanie, $w$ jakiego typu sprawach realizowane jest prawo dziecka do wyrażania opinii we własnej kwestii ${ }^{72}$.

Wydaje się, że podmiotowe traktowanie dziecka powinno uzasadniać zapoznanie się z jego zdaniem w świetle prowadzonego postępowania. Jednak, jak pokazują dane, praktyka sądów jest w tym zakresie inna.

Natomiast jeśli chodzi o badania $\mathrm{z}$ udziałem małoletnich $\mathrm{w}$ postępowaniu karnym, to sytuacja napawa optymizmem, gdyż sukcesywnie z każdym rokiem rośnie liczba przesłuchiwanych dzieci jako pokrzywdzonych w trybie art. 185a k.p.k. W roku 2003 przesłuchano 1303 takie osoby, a w 2012 - 5426 osób. Jednocześnie zmalała liczba wielokrotnych przesłuchań pokrzywdzonych dzieci. Z powodu żądania oskarżonego w 2004 roku jeszcze raz przesłuchano 4,68\% ogółu przesłuchanych dzieci, natomiast w 2012 roku - 1,63\% ogółu przesłuchanych. Z powodu ujawnienia istotnych okoliczności, których wyjaśnienie wymaga ponownego przesłuchania, w 2004 roku przesłuchano więcej niż jeden raz 6,1\% ogółu pokrzywdzonych dzieci, a 2012 roku już tylko 0,6\% ogółu dzieci. Dane statystyczne dotyczące przesłuchań małoletnich świadków w trybie $185 \mathrm{~b}$ k.p.k. również są korzystne. Zgodnie z nimi liczba osób przesłuchiwanych w tym trybie wzrosła: od sierpnia 2005 roku do sierpnia 2006 roku przesłuchano 572 osoby, natomiast tylko w 2012 roku już 1162 osoby $^{73}$.

\section{Child friendly justice - psychological and legal perspective}

\section{Summary}

From a psychological perspective, a child hearing is a special form of interaction betweenan adult person and a child. The article is presenting the proposition of a child hearing method, which allows the judge to acquire important information for the proceedings outcome, on the minor and its needs, as well as not to involve the minor in its parent's conflict, and does not burden him with the responsibility for the judge's decisions. The elaborations were supplemented with a presentation empirical finding concerning the said legal institution.

Keywords: psychology, children's rights, child hearing, hearing standards, child protection in civil law proceedings, child protection in criminal law proceedings.

72 Zakres prezentowanych badań jest zdecydowanie bardziej złożony niż prezentowane wcześniej wyniki innych autorów. Całość materiału O. Trocha, op. cit., s. 55-81.

73 S. Skubisz-Ślusarczyk, I. Zieniewicz, op. cit., s. 299-301.

Nowa Kodyfikacja Prawa Karnego 50, 2018

(C) for this edition by CNS 